\title{
Bilateral Thalamic Lesions Associated With Atezolizumab-Induced Autoimmune Encephalitis
}

Haruo Nishijima, MD, PhD, Chieko Suzuki, MD, PhD, Tomoya Kon, MD, PhD, Takashi Nakamura, MD, Hisashi Tanaka, MD, PhD, Yui Sakamoto, MD, and Masahiko Tomiyama, MD, PhD

Neurology ${ }^{\circledR} 2021 ; 96: 126-127$. doi:10.1212/WNL.0000000000011297

Figure Reversible Thalamic Lesions With Atezolizumab-Induced Encephalitis Before and After Immunotherapy

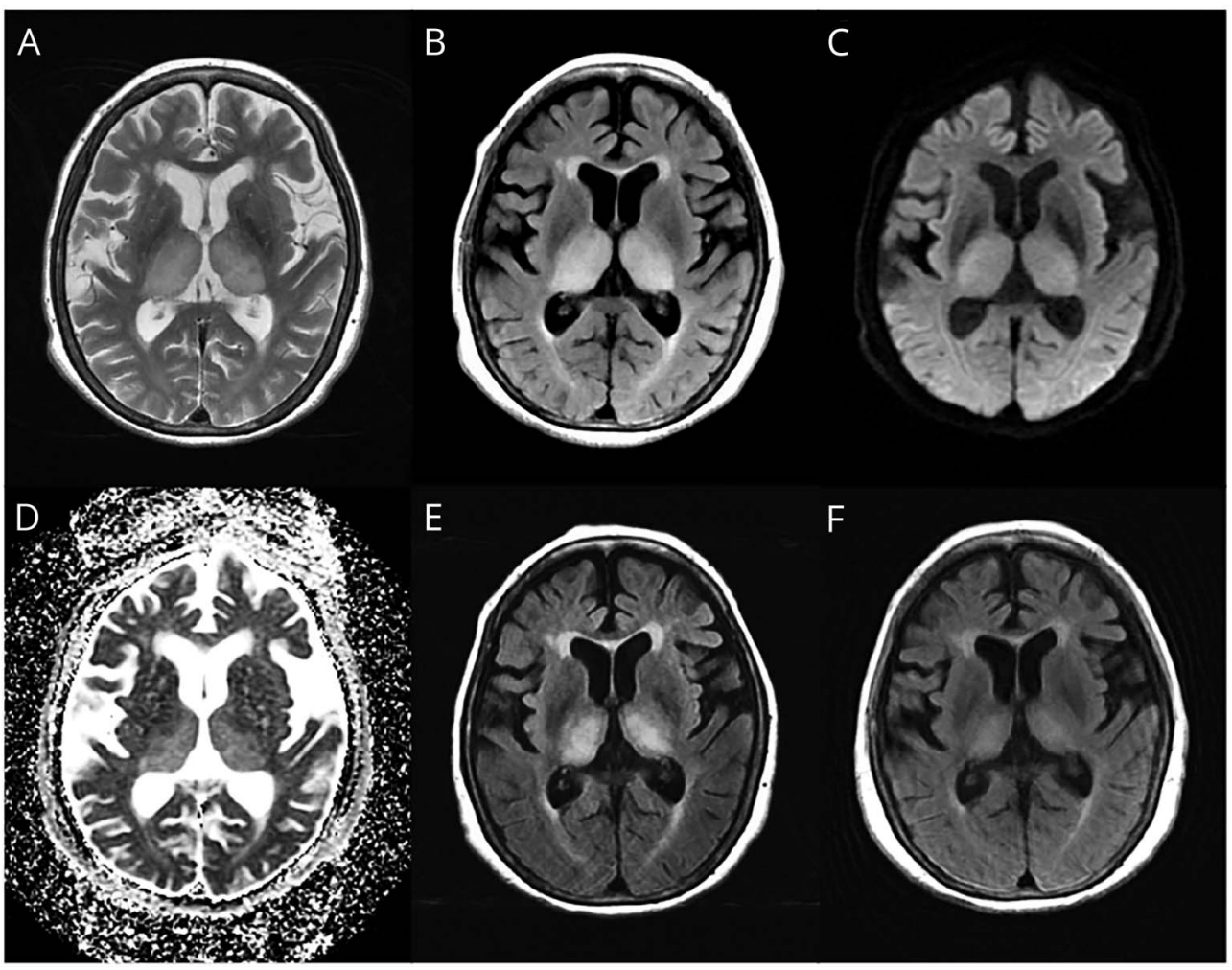

MRI initially showed high signals bilaterally in thalamus on T2-weighted (A), fluid-attenuated inversion recovery (B), and diffusion-weighted images (C), and apparent diffusion coefficient map (D). Lesion size reduced on fluid-attenuated inversion recovery images 3 (E) and 7 weeks (F) after immunotherapy.

\section{Correspondence}

Dr. Nishijima

hnishijima-tky@umin.ac.jp

A 72-year-old woman presented with a 6-week history of gait disturbance and mild disturbance of consciousness. For 9 months, she had been treated for advanced non-small cell lung cancer with atezolizumab. MRI revealed symmetrical high signal in the thalamus bilaterally (figure). She did not have evidence of cancer recurrence or metastases. Serum autoimmune antibodies were absent (anti-AQP4, anti-MOG, anti-amphiphysin, CV2, PNMA2 [Ma2/Ta], Ri, Yo, Hu, recoverin, SOX1, titin, zic4, GAD65, and $\operatorname{Tr}$ [DNER]). In the CSF, she had high immunoglobulin $\mathrm{G}$ index and positive oligoclonal bands but normal myelin basic protein, absent antiNMDA receptor and anti-MOG antibodies, and no evidence of infection. Cytology was normal. She was diagnosed with autoimmune encephalitis associated with atezolizumab treatment and 
treated with steroids and IV immunoglobulin 9 weeks after the onset of symptoms. The size of the lesions decreased after immunotherapy started, but she remained bedridden.

\section{Study Funding}

No targeted funding reported.

\section{Disclosure}

The authors report no disclosures relevant to the manuscript. Go to Neurology.org/N for full disclosures.

Appendix Authors

\begin{tabular}{lll}
\hline Name & Location & Contribution \\
\hline $\begin{array}{l}\text { Haruo } \\
\text { Mishijima, }\end{array}$ & $\begin{array}{l}\text { Hirosaki University } \\
\text { Graduate School of } \\
\text { Medicine, Japan }\end{array}$ & $\begin{array}{l}\text { Designed and conceptualized } \\
\text { study, analyzed the data, } \\
\text { drafted the manuscript for } \\
\text { intellectual content }\end{array}$ \\
\hline $\begin{array}{l}\text { Chieko } \\
\text { Suzuki, MD, } \\
\text { PhD }\end{array}$ & $\begin{array}{l}\text { Hirosaki University } \\
\text { Graduate School of }\end{array}$ & $\begin{array}{l}\text { Patient care and acquisition } \\
\text { of data, interpreted the data, } \\
\text { revised the manuscript for } \\
\text { intellectual content }\end{array}$ \\
\end{tabular}

Appendix (continued)

\begin{tabular}{lll}
\hline Name & Location & Contribution \\
$\begin{array}{l}\text { Tomoya Kon, } \\
\text { MD, PhD }\end{array}$ & $\begin{array}{l}\text { Hirosaki University } \\
\text { Graduate School of } \\
\text { Medicine, Japan }\end{array}$ & $\begin{array}{l}\text { Patient care and acquisition } \\
\text { of data, revised the } \\
\text { manuscript for intellectual } \\
\text { content }\end{array}$ \\
\hline $\begin{array}{l}\text { Takashi } \\
\text { Nakamura, } \\
\text { MD }\end{array}$ & $\begin{array}{l}\text { Hirosaki University } \\
\text { oraduate School }\end{array}$ & $\begin{array}{l}\text { Patient care and acquisition } \\
\text { of data }\end{array}$ \\
\hline $\begin{array}{l}\text { Hisashi } \\
\text { Tanaka, MD, } \\
\text { PhD }\end{array}$ & $\begin{array}{l}\text { Hirosaki University } \\
\text { Graduate School of } \\
\text { Medicine, Japan }\end{array}$ & $\begin{array}{l}\text { Patient care and acquisition } \\
\text { of data, revised the } \\
\text { manuscript for intellectual } \\
\text { content }\end{array}$ \\
\hline $\begin{array}{l}\text { Yui } \\
\text { Sakamoto, } \\
\text { MD }\end{array}$ & $\begin{array}{l}\text { Hirosaki University } \\
\text { Graduate School of }\end{array}$ & $\begin{array}{l}\text { Patient care and acquisition } \\
\text { of data, revised the } \\
\text { manuscript for intellectual } \\
\text { content }\end{array}$ \\
\hline $\begin{array}{l}\text { Masahicine, Japan } \\
\text { MD, PhD }\end{array}$ & $\begin{array}{l}\text { Medicine, Japan } \\
\text { Hirosaki University }\end{array}$ & $\begin{array}{l}\text { Interpreted the data, } \\
\text { revised the manuscript } \\
\text { for intellectual } \\
\text { content }\end{array}$ \\
\hline
\end{tabular}

\section{NEW EPISODE}

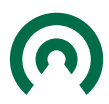

$\underset{\text { PoOCAST }}{\text { Neurology }}$

January 19, 2021

\section{Increasing Out-of-Pocket Costs for Neurologic Care for Privately Insured Patients (see p. 94)}

In the first segment, Dr. Stacey Clardy receives an update from Dr. Pushpa Narayanaswami on the management of myasthenia gravis. In the second part of the podcast, Dr. Jeffrey Ratliff talks with Dr. Chloe Hill about patients' out-of-pocket costs in neurology.

Disclosures can be found at Neurology.org.

CME Opportunity: Listen to this week's Neurology ${ }^{\circledR}$ Podcast and earn 0.5 AMA PRA Category 1 CME Credits ${ }^{\mathrm{TM}}$ by completing the online podcast quiz. 


\section{Neurology}

\section{Bilateral Thalamic Lesions Associated With Atezolizumab-Induced Autoimmune Encephalitis}

Haruo Nishijima, Chieko Suzuki, Tomoya Kon, et al.

Neurology 2021;96;126-127 Published Online before print December 2, 2020

DOI 10.1212/WNL.0000000000011297

\section{This information is current as of December 2, 2020}

Updated Information \& Services

Citations

Subspecialty Collections

Permissions \& Licensing

Reprints including high resolution figures, can be found at: http://n.neurology.org/content/96/3/126.full

This article has been cited by 1 HighWire-hosted articles: http://n.neurology.org/content/96/3/126.full\#\#otherarticles

This article, along with others on similar topics, appears in the following collection(s):

All Clinical Neurology

http://n.neurology.org/cgi/collection/all_clinical_neurology

Autoimmune diseases

http://n.neurology.org/cgi/collection/autoimmune_diseases

Encephalitis

http://n.neurology.org/cgi/collection/encephalitis

MRI

http://n.neurology.org/cgi/collection/mri

Information about reproducing this article in parts (figures,tables) or in its entirety can be found online at:

http://www.neurology.org/about/about_the_journal\#permissions

Information about ordering reprints can be found online:

http://n.neurology.org/subscribers/advertise

Neurology ${ }^{\circledR}$ is the official journal of the American Academy of Neurology. Published continuously since 1951, it is now a weekly with 48 issues per year. Copyright (C 2020 American Academy of Neurology. All rights reserved. Print ISSN: 0028-3878. Online ISSN: 1526-632X.

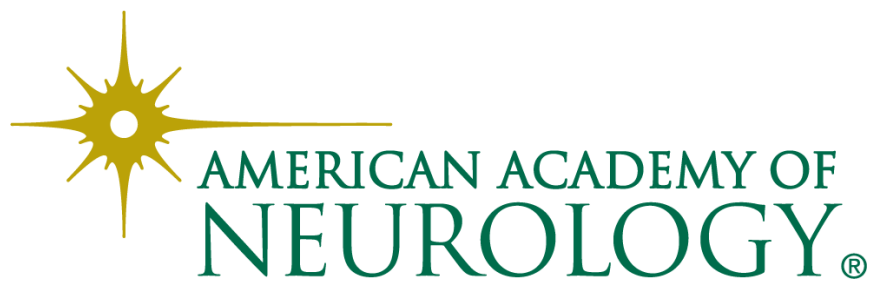

